NATALIA MAMUL

Państwowa Wyższa Szkoła Zawodowa w Skierniewicach

\title{
JĘZYK JAKO CZYNNIK ZAKORZENIENIA W TOŻSAMOŚCI NARODOWEJ NA PRZYKŁADZIE BIAŁORUSKOJĘZYCZNEJ INTELIGENCJI NA BIAŁORUSI
}

Białoruś - jako typowe państwo pogranicza - to kraj wieloetniczny. Kraj, w którego obrębie współistnieją różne kultury, wyznania i języki. Od zarania dziejów tereny wchodzące obecnie w skład państwa białoruskiego były pograniczem cywilizacji bizantyjskiej i zachodnioeuropejskiej. Ścieranie się rozmaitych wpływów językowych, kulturowych, religijnych i historycznych z jednej strony można postrzegać jako ograniczające dla procesów unarodowienia, $z$ drugiej zaś można widzieć $\mathrm{w}$ tym potężny potencjał rozwojowy. Na przykład Elżbieta Smułkowa (2002) szansę dla Białorusi widzi właśnie w tej różnorodności. Uważa, że dostrzeżenie i docenienie jej europejskich korzeni, a także postępująca globalizacja, rozszerzenie Unii Europejskiej, coraz większe poszanowanie dla heterogeniczności w naszej części Europy - wszystko to otworzy Białoruś na demokratyzację i, co za tym idzie, pozwoli na skonsolidowanie własnej tożsamości.

Obecną sytuację socjolingwistyczną na Białorusi można określić mianem społecznie uwarunkowanej dyglosji. Rosyjski jest językiem elit rządzących, szkolnictwa na wszystkich szczeblach, kultury popularnej i środków masowego przekazu. Mieszkańcy miast prawie wyłącznie posługują się językiem rosyjskim, mieszkańcy wsi głównie używają gwar białoruskich (mówią tak zwaną trasianka). Kiedy za rządów Aleksandra Łukaszenki język białoruski znowu popadł $\mathrm{w}$ niełaskę, po raz kolejny stał się silnym symbolem odrodzenia narodowego i narzędziem walki w rękach opozycji. Obecnie mówienie po białorusku jest wyrazem sprzeciwu wobec istniejącego reżimu, a sam język białoruski jest postrzegany jako język przyszłych elit rządzących. „Mówienie po białorusku to akcja polityczna; mówić po białorusku znaczy przeciwstawiać

Adres do korespondencji: natalia.mamul@gmail.com 
się autorytarnemu reżymowi Łukaszenki. Powiązanie między tożsamością językową a polityką stanowi bazę ideologiczną dla Frontu Ludowego ${ }^{1}$ i organizacji zrzeszających intelektualistów" (Goujon 1999, s. 670).

\section{ZARYS HISTORII JĘZYKA BIAŁORUSKIEGO}

W różnych okresach historycznych język białoruski stanowił przeciwwagę dla dominującego nurtu kultury rosyjskiej bądź polskiej. Pod tym względem historię Białorusi można podzielić na kilka etapów: okres połocki (IX-XIII w.), okres białorusko-litewski (XIII-XVI w.), okres polski (XVI-XVIII w.), okres rosyjski (XIX w.-1917 r.), okres radziecki (1917-1991) i okres postradziecki (od roku 1991 do chwili obecnej) (por. Ihnatouski 1992, s. 28-30).

Okres białorusko-litewski (XIII-XVI), a w szczególności koniec XV - początek XVI wieku jest uznawany za „złoty wiek” kultury białoruskiej (m.in. Krawcewicz 2003). Począwszy od 1315 do 1696 r. białoruski był językiem urzędowym, początkowo w Księstwie Litewskim, a następnie, od roku 1569, w Wielkim Księstwie Litewskim, co znacząco przyczyniło się do jego rozwoju. „Z początkiem czternastego mamy już Wielkie Księstwo Litewskie, w którym kancelarie książęce posługiwały się wyłącznie zapisem starobiałoruskim (podług aluzji Długosza należy mniemać, że król Władysław Jagiełło nie wyuczył się polszczyzny; jako monarcha nie musiał" (Janowicz 2001, s. 76)). O wysokim statusie języka białoruskiego $\mathrm{w}$ tamtych czasach świadczy chociażby fakt, że „[...] kiedy Polacy na początku XV wieku chcieli lepiej zrozumieć niektóre statuty pisane po łacinie, przekładali je na białoruski” (Garoszka 1994, s. 101). Sekretarz wielkiego księcia Aleksandra, urodzony w Wilnie, prałat Erazmus Witeli, w sprawozdaniu z 31 marca 1501 r. składanym w Rzymie czyni następującą uwagę: „[...] ponieważ Białorusini zamieszkują środek Księstwa, a ich język [w porównaniu z litewskim] jest ładniejszy i łatwiejszy do nauki, jest on w powszechnym użyciu" (Garoszka 1994, s. 101.). Jednym z najbardziej znaczących faktów kultury i języka białoruskiego było niewątpliwie przetłumaczenie na język białoruski i wydrukowanie Biblii w Pradze, w latach 1517-1519 przez Franciszka Skarynę z Połocka (por. Brzeziecki, Nocuń 2007, s. 15) (była to druga - po czeskiej, wydrukowanej w 1488 r. - słowiańska drukowana księga).

Pozycja białoruskiego jako języka oficjalnego zaczęła słabnąć w XVI wieku, choć nadal pozostawał on językiem urzędowym, do połowy XVII wieku był językiem kancelarii i językiem dworu Wielkiego Księstwa Litewskiego (Straczuk 1999, s. 22). W 1696 r. językiem urzędowym ogłoszono polski, zastąpił język białoruski w oficjalnych dokumentach Wielkiego Księstwa Litewskiego (Zaprudnik 1996, s. XXIV). Pod koniec XVII wieku publikacje białoruskie już

\footnotetext{
${ }^{1}$ Białoruski Front Ludowy (biał. BNF - Biełaruski Narodny Front), opozycyjna partia na Białorusi.
} 
nie powstawały, drukiem wychodziły przeważnie książki polskie. Jeśli chodzi o edukację, to kształcenie zapewniały zakony rzymskokatolickie, w których używano języków polskiego i łacińskiego, a w języku białoruskim jedynie Kościół Unicki (Szybieka 2002, s. 11). Język białoruski został zepchnięty głównie do sfery kultury ludowej i języka potocznego. W „podsumowaniu” tak zwanego okresu białorusko-litewskiego należy podkreślić fakt, że Wielkie Księstwo Litewskie pozwoliło Białorusinom, a przynajmniej znacznej części elit politycznych i intelektualnych, uwolnić się spod wpływu Moskwy i stworzyło podwaliny pod dalszy rozwój narodu białoruskiego (por. Stone 2001, s. 337).

W 1795 r. Wielkie Księstwo Litewskie przestało istnieć i wtedy na jego dawnych wschodnich połaciach wprowadzono urzędową nazwę Białoruś. Zaczął się okres intensywnej rusyfikacji, a za czasów panowania Pawła I i Aleksandra I (1796-1825) - polonizacji, obaj ci monarchowie uznawali bowiem te ziemie za kraj polski i starali się zyskać przychylność polskojęzycznej szlachty. Kościół Unicki, do którego należało około $70 \%$ mieszkańców (por. Brzeziecki, Nocuń 2007, s. 16), w 1794 r. został zakazany na mocy postanowienia Katarzyny II, a unitów przepisywano całymi parafiami na prawosławie (por. Szybieka 2002). W 1839 r. zakazano używania języka białoruskiego w Kościele i Cerkwi oraz nauczania w tym języku. W 1865 r. wprowadzono zakaz stosowania białoruskiego w druku. Tak oto $\mathrm{w}$ okresie odrodzenia świadomości pansłowiańskiej piśmiennictwo białoruskie nie mogło się swobodnie rozwijać. Ponieważ język białoruski nie istniał $\mathrm{w}$ życiu oficjalnym, ani też nie był używany w szkolnictwie, do wieku XIX nie powstała jednolita, powszechnie obowiązująca ortografia i normy leksykalne. Pierwszy słownik języka białoruskiego wydano pod redakcją Iwana Nosowicza w 1870 r. w Petersburgu. Dociekliwe badania nad językiem prowadził też E. F. Karskij, autor legendarnych dwutomowych Biełorusow (Warszawa 1908-1911).

W ostatnich dekadach XX wieku język białoruski stał się symbolem niezależności Białorusi. Pierwszy postradziecki rząd Stanisława Szuszkiewicza budowę niezależnego państwa Białoruś rozpoczął od powszechnej białorutenizacji, propagował oświeceniowy model budowania tożsamości zbiorowej poprzez edukowanie mas, które miałyby „dorosnąć” do wspólnoty kultury i wartości. Po odzyskaniu niepodległości przyjęto ustawę nadającą językowi białoruskiemu status języka oficjalnego, chociaż elity polityczne pozostałe po okresie pierestrojki przeważnie były rosyjskojęzyczne. Niestety powszechne wprowadzenie języka białoruskiego do szkolnictwa (w tym także wyższego) i jako jednego z egzaminów wstępnych na studia wzbudziło obawy w większości rosyjskojęzycznej ludności. Wprowadzenie języka białoruskiego do środowiska pracy spotkało się ze sprzeciwem rosyjskojęzycznych specjalistów z wielu dziedzin, którzy nie chcieli, aby o zajmowanym przez nich stanowisku lub otrzymywanym wynagrodzeniu decydowały kompetencje językowe, a nie wiedza i doświadczenie. Nie należy zapominać, że na Białorusi mieszkała pokaźna mniej- 
szość rosyjska, w latach dziewięćdziesiątych licząca 1,5 miliona osób. Ponadto dwa miliony weteranów drugiej wojny światowej niechętnie odniosły się do pomniejszania ich zasług w walce o wolność i przyszłość ZSRR, które to państwo w świetle nowej ideologii postrzegano jako agresora (Mironowicz 2002). Mimo niezadowolenia wielu warstw społecznych na początku lat dziewięćdziesiątych język białoruski zaczął jednak stopniowo wypierać rosyjski w szkolnictwie powszechnym, środowisku uniwersyteckim, nawet w administracji, a także wśród szerzej rozumianej inteligencji i w środowiskach twórczych.

Sytuacja jednak zmieniła się. „W 1992 r., w niespełna rok po uzyskaniu niepodległości, siły demokratyczne straciły popularność. Ta niezdolność do mobilizacji obywateli, którzy początkowo popierali przemiany polityczne $\mathrm{w}$ kraju, zmarginalizowała białoruską opozycję. [...] System polityczny był tak słaby, że można mówić o istnieniu próżni politycznej. Próżnia ta umożliwiła Łukaszence błyskawiczne dojście do władzy w 1994 r." (Lenzi 2002, s. 405). Podczas wyborów z roku 1994 społeczeństwo białoruskie nie przedłużyło mandatu władzom demokratycznym. Jeśli zaś chodzi o politykę językową wybranego prezydenta, to zastosował on następujący model: „od negacji języka do negacji narodu, a w konsekwencji do negacji własnego państwa" (Andrusieczko 2002, s. 97). Kiedy za rządów Łukaszenki język białoruski znowu popadł w niełaskę, ponownie stał się ważnym symbolem i narzędziem walki w rękach opozycji.

Analiza przebiegu kampanii wyborczych z lat 2001, 2006 i 2010 wykazuje, że stałym elektoratem Łukaszenki jest ludność kreolska. Walery Bułhakau (2002, s. 77-78) nazywa kreolami obywateli białoruskich posługujących się „łamanym językiem rosyjskim i wciąż postrzegających Białoruś jako część imperium rosyjskiego”, „stanowią [oni] rzecz jasna główne źródło rozwoju reżimu politycznego Łukaszenki". Właśnie kreolska część społeczeństwa powinna, zdaniem Bułhakaua, stanowić główny cel oddziaływania sił demokratycznych. Zadaniem elit białoruskich jest sprawienie, aby proces demokratyzacji społeczeństwa był nieodwracalny. Cel ten można osiągnąć przez wdrażanie kreoli do kultury białoruskiej, bez czego proces przemian narodowych na Białorusi pozostanie nie dokończony. W odróżnieniu od osób narodowo zdeklarowanych ambiwalentni Białorusini mają do wyboru trzy rodzaje afiliacji kulturowej: przynależność do kultury białoruskiej, afiliację kreolską (czyli ambiwalencję kulturową, jeśli użyjemy terminu Antoniny Kłoskowskiej) oraz afiliację z niezmodyfikowaną kulturą rosyjską. Większość obywateli białoruskich nadal cechuje brak zakorzenienia w jakiejkolwiek kulturze, ambiwalencja kulturowa, tożsamość kreolska.

\section{METODA I DOBÓR PRÓBY}

Przedmiotem badania są utrwalone $\mathrm{w}$ formie zapisów narracje dotyczące przebiegu życia narratorów. Wywiady nagrano $z$ wykorzystaniem metody badawczej zaproponowanej przez Fritza Schützego i określanej mianem wywiadu 
narracyjnego ${ }^{2}$. Bazując na dorobku językoznawstwa, socjologii interpretatywnej (etnometodologii i analizy konwersacyjnej), socjologii fenomenologicznej i socjologii interakcji Ervinga Goffmana (por. Czyżewski 1997; Rokuszewska-Pawełek 1996), autor ten opracował technikę wywiadu „minimalizującego wpływ przeprowadzającego wywiad i maksymalizującego ekspresję osoby badanej co do jej spraw osobistych" (Helling 1990, s. 15). Ze względu na hermetyczność środowiska, z którego wywodzą się osoby badane, a także niesprzyjające swobodnym badaniom i obserwacjom socjologicznym warunki społeczno-polityczne na Białorusi w objętym badaniem okresie (1999-2008) przy doborze narratorów zastosowano metodę „kuli śniegowej” 3 (snowball sampling). Wśród podstawowych kryteriów doboru osób badanych należy wymienić autodeklarację przynależności do białoruskiej grupy narodowej (za Antoniną Kłoskowską [1996] odróżniam identyfikację narodową, tożsamą z autodeklaracją przynależności do grupy narodowej, i walencję kulturową ${ }^{4}$, która $z$ kolei określa stopień przyswojenia kultury narodowej) oraz autodeklarację posługiwania się językiem białoruskim we wszystkich lub wybranych sferach życia. Wszyscy narratorzy są obywatelami Białorusi. Czas trwania każdego z omawianych wywiadów wynosi nieco powyżej półtorej godziny. W transkrypcji zastosowano uproszczoną wersję systemu zapisu opracowanego przez Gail Jefferson ${ }^{5}$.

Badana zbiorowość tworzy specyficzną i hermetyczną wspólnotę, którą proponuję nazwać wspólnotą interpretacyjną. Termin ten oznaczałby perspektywę, punkt widzenia, sposób organizowania doświadczeń, który zapanował w pewnym środowisku (tożsamym w dużej mierze ze środowiskiem inteligenckim), co sprawiło, że przyjęte przez badane jednostki kategorie myślenia o rzeczywistości, kategorie ważności i nieważności połączyły ich we wspólnotę czy też quasi-wspólnotę. Badana zbiorowość tworzy środowisko odpowiadające historycznie ugruntowanemu - zwłaszcza na obszarze dziewiętnastowiecznej Rosji i na ówczesnych terenach polskich - zjawisku inteligenckich kólek (Berlin 2003). Analiza koncentruje się na wypowiedziach o charakterze autobiograficznym, które odsłaniają społecznie uformowane sposoby ujmowania własnych

2 Opis metody wywiadu narracyjnego można znaleźć w następujących pracach: Chanfrault-Duchet 1995; Helling 1990; Hermanns 1987; Kaźmierska 1997; Piotrowski 1997; Prawda 1989; Riemann 2000; Schütze 1990, 1997.

3 Wybór doboru lawinowego czy metody „kuli śniegowej” jest uzasadniony zwłaszcza wtedy, gdy istnieje trudność dotarcia do poszukiwanych osób oraz gdy sieci społecznych powiązań same W sobie mogą stanowić przedmiot badań. W przypadku tego podejścia wielokrotnie powtórzona jest sytuacja, w której rozmówca wskazuje kolejnych respondentów.

4 Zdaniem Antoniny Kłoskowskiej (1996, s. 128), walencję kulturową osiąga się przez nabywanie kompetencji kulturowej oraz uznanie kultury „za własną, bliską, odpowiadającą potrzebom hubrystycznym, czyli wzmagającą poczucie własnej wartości, godności, poczucie uczestnictwa we wspólnocie".

5 Jest to jeden z systemów oznakowania szczegółów intonacyjnych, nacisku, pauz oraz charakterystycznych cech wypowiedzi. Wywodzi się ze szkoły analizy konwersacyjnej (CA - Conversation Analysis). Szczegółowe opracowania dotyczące stosowanych systemów zapisu są omówione w: 
doświadczeń życiowych, z zastosowaniem wewnętrznych kategorii narratorów. Zakładamy, że relacjonujący swoją biografię narratorzy dokonują autoeksplanacyjnej pracy o charakterze hermeneutycznym. Owa hermeneutyka własnej biografii dokonywana jest przez narratorów - mniej lub bardziej świadomie - z perspektywy ich życiowych rozstrzygnięć, wyborów, osiągnięć, innymi słowy $-z$ partykularnej perspektywy ich pozycji w polu społecznych relacji.

Zadaniem badacza i polem problemowym podjętej analizy jest zatem nie tylko systematyczny opis odsłoniętych przez narratorów procesów biograficznych tematycznie zorientowanych na kształtowanie się ich tożsamości narodowej, ale również wskazanie na przedsądy, światopoglądy, ideologie i wszelkie społecznie zagregowane zasoby symboliczne leżące u podstaw dokonanych przez nich hermeneutycznych rozstrzygnięć. Interpretacja nie jest sprawą swobodnej imaginacji, nie jest czymś przypadkowym i dowolnym, przeciwnie jest bardzo ograniczona przez siłę kulturowych konwencji. To te czynniki składają się na zasób narzędzi interpretacji, jakimi dysponujemy, to te czynniki umożliwiają skonstruowanie rzeczywistości, jaką poznajemy.

$\mathrm{W}$ aktach interpretowania własnych biografii narratorzy przekraczają granicę wiedzy porządkującej świat, w którym wyrastali i która została im narzucona przez kulturę dominującą i prawomocną. Analiza pokazuje, że dokonując tego rodzaju przekroczeń, niektórzy decydują się na fundamentalne posunięcia o charakterze politycznym. Traktujemy zatem analizowane narracje jak formułowane przez narratorów naiwne teorie porządkujące i wyjaśniające ich bio-

Atkinson, Heritage 1984; Hutchby, Wooffitt 1998; Sachs i in. 1974. Oto zastosowane symbole i ich znaczenie:

$\begin{array}{ll}\frac{\text { nie }}{\text { TAK }} & \text { wypowiedź z naciskiem } \\ \text { ojak sadzę } & \text { głośna wypowiedź } \\ \text { wła:śnie } & \text { wypowiedź przygłuszonym tonem } \\ \text { tak-tak-tak } & \text { wydłużona głoska } \\ \text { cóż/ } & \text { wypowiedziana jednym tchem sekwencja słów } \\ \text { cóź } & \text { intonacja wznosząca (jak w pytaniu) } \\ \text { chociaż// } & \text { intonacja opadająca (jak na końcu zdania twierdzącego) } \\ \text { chociaż\# } & \text { wypowiedź nieoczekiwanie przerwana przez narratora } \\ & \text { wypowiedź przerwana przez interlokutora (osobę trzecią; zakłócenie } \\ (4) & \text { innego rodzaju) } \\ (.) & \text { pauza czterosekundowa } \\ (\ldots) & \text { mikro-pauza (ok. 0,2 sekundy) czyli najmniejsza zauważalna pauza } \\ (\text { niestety) } & \text { nieczytelna wypowiedź } \\ ((\text { śmiech)) } & \text { przypuszczalna wypowiedź niezbyt czytelna }\end{array}$

A: mam [jednak pewne...]

B: [nie możemy....... jednoczesne mówienie kilku osób

A: właśnie $=$

$\mathrm{B}:=$ właśnie

sygnalizuje przejście między kolejkami bez pauzy 
grafie, a w dalszej kolejności, przez analogię do Mannheimowskiej socjologii wiedzy, partykularyzujemy owe teorie, wskazując społeczne i historyczne konteksty, w których są one zakorzenione, staramy się także odsłonić interesy, którym służą i które leżą u podstaw ich sformułowania. Na podstawie wywiadów biograficznych z przedstawicielami białoruskojęzycznej inteligencji na Białorusi odsłania się proces odkrywania przez narratorów w życiu dorosłym doniosłości języka ojczystego jako wyznacznika przynależności narodowej, proces uświadamiania sobie roli języka białoruskiego w życiu jednostki, a także zbiorowości etnicznej. Świadome uczenie się języka stanowi jeden z etapów krystalizacji tożsamości narodowej współczesnych Białorusinów. W ślad za językiem podąża uczestnictwo w białoruskiej kulturze symbolicznej i sięganie do zasobów historii oraz pamięci zbiorowej, co ostatecznie umożliwia walencję kulturową (Kłoskowska 1996), czyli świadomą identyfikację z ojczyzną w sensie symbolicznym, rozumianą szerzej niż odniesienie czysto terytorialne.

\section{PRZYPADEK WIKTORA}

Wiktor urodził się w 1959 r. w niewielkim zachodniobiałoruskim mieście w „zwyczajnej” rodzinie „radzieckich inteligentów” [2:23-24], „inteligentów w pierwszym pokoleniu” [2:21-22]. Jak narrator „później ustalił pracując w archiwach" [2:22-23], wcześniejsze pokolenia były pochodzenia chłopskiego. Można wnioskować, że rodzice Wiktora przeszli typową w Związku Radzieckim drogę awansu społecznego polegającą na zdobyciu wykształcenia i przeprowadzeniu się ze wsi do miasta. Podobnie jak przeważająca większość mieszkańców białoruskich miast Wiktor rozmawiał $z$ rodzicami po rosyjsku ${ }^{6}$. Język białoruski słyszał u dziadków ${ }^{7}$, którzy go wychowywali do drugiego roku życia, później Wiktor przebywał u nich mniej regularnie. Świadomość różnic językowych w dzieciństwie nie istniała: „(3) cóż\dopiero później zacząłem rozróżniać język białoruski i rosyjski oczywiście" [2:29]. W $1966 \mathrm{r}$. Wiktor rozpoczął naukę w szkole podstawowej, „zwykłej radzieckiej białoruskiej szkole”, w której język białoruski był nieobecny. Przypomina sobie, że dopiero później, w szkole średniej, wprowadzono dwie godziny tygodniowo języka i literatury białoruskiej. Status tych zajęć był niski, traktowano je jako przedmioty „drugorzędne”, nie-

${ }^{6}$ Nośnikiem narzucanego radzieckiego wzoru cywilizacyjnego, a co za tym idzie - nośnikiem edukacji, postępu, urbanizacji, industrializacji i awansu społecznego realizowanego w ramach tego wzoru w Białoruskiej Republice Radzieckiej (w okresie 1918-1990) był język rosyjski (zob. m.in. Radzik 2001, 2002; Tereshkovich 2001).

7 Powszechna rusyfikacja (równoznaczna w ZSRR z sowietyzacja) obejmowała kulturę popularną, wszystkie szczeble szkolnictwa, stanowiła furtkę do awansu społecznego i zawodowego. W rezultacie najbardziej „dziewiczym” terenem pozostały obszary wiejskie, których mieszkańcy nadal mówili po białorusku (lub mieszanką białorusko-ukraińską czy białorusko-polską), wśród mieszkańców miast natomiast język białoruski miał rangę języka osób niewykształconych, chłopów mówiących „trasianką". 
potrzebne i nieatrakcyjne [2:33-34]. Na etapie szkoły podstawowej narrator nie zastanawiał się nad swoją przynależnością narodową. Zaczął dostrzegać „obcych" w ramach wspólnoty sąsiedzkiej na płaszczyźnie obyczajowo-kulturowej. Jako „etnicznie innych” wyróżniano miejscowych Polaków, Cyganów i Żydów. $Z$ obecnej perspektywy eksperta Wiktor dodaje, że na Białorusi zawsze dało się zaobserwować przejawy „obyczajowego antysemityzmu” [3:2]. Określając etnicznych innych, Wiktor zarazem definiuje obszar poczucia wspólnoty: „między Rosjanami, Białorusinami a Ukraińcami nie było żadnej różnicy" [3:3-4]. Podsumowuje, że nie pamięta niczego, co by się wiązało z białoruskością czy sprzyjało kształtowaniu się świadomości narodowej Białorusina na etapie edukacji podstawowej i średniej. Samookreślenie budowane było w opozycji do „etnicznych innych”, a mianowicie kończąc szkołę średnią narrator wiedział jedynie, że nie jest „ani Cyganem, ani Żydem, ani Polakiem” [3:5-6].

Pięcioletnia edukacja na wydziale historycznym również nie sprzyjała kształtowaniu się białoruskiej tożsamości narodowej. Rosyjski pozostał językiem wykładowym, także w czasie zajęć z historii Białorusi. Wiktor zwraca uwagę na fakt, że historia Białorusi była wykładana jako składowa historii Rosji, „nie było więc poczucia, że jest to historia odmienna od historii Rosji" [3:15]. Język białoruski słyszał jedynie w czasie wyjazdów terenowych na wieś. Narrator zauważa, że jako student nadal nie był świadom, że mieszkańcy wsi mówią po białorusku. Język ten uważano za „jaką́ gwarę wiejska (.) którą posługują się niezbyt wykształceni ludzie" [3:20-21]. Stereotyp ten rozpowszechniały media, $\mathrm{w}$ tym telewizja białoruska, oferująca niskiej jakości programy białoruskojęzyczne. Narrator wspomina, że gdy tylko zaczynał się „jakiś program białoruski, natychmiast miało się ochotę wyłączyć telewizor bo $z$ reguły były to jakieś staruszki śpiewające coś strasznie nudnego ((westchnienie)) co oczywiście do kultury białoruskiej nie zachęcało" [3:23-24].

Wśród wykładowców uniwersyteckich Wiktor nie spotkał osób, które próbowałyby krzewić ideę białoruską lub obudzić świadomość narodową studentów. Zastanawiając się nad przyczyną braku w okresie 1976-1981 akademickich autorytetów promujących ideę białoruskości, Wiktor przywołuje postać profesora Tkaczoua, który w latach dziewięćdziesiątych stał się „aktywnym, świadomym Białorusinem” [3:29-30]. Konstatuje: „potem gdy doszło do tych wszystkich przemian nie mogło to tak szybko zmienić świadomości tegoż Tkaczoua tak od razu" [3:33-34]. Narrator wnioskuje, że widocznie wcześniejsze dekady i ,audytorium studenckie nie było odpowiednim miejscem by bezpiecznie wygłaszać swoje opinie na tematy narodowościowe $\backslash "$ [3:30-32]. Profesor Tkaczou symbolizuje zatem na poziomie narracji „uśpioną” białoruską świadomość, która samą siebie może rozpoznać dopiero w sprzyjających okolicznościach albo - co lepiej chyba oddaje intencję narratora - kiedy nadejdzie jej czas. Czyniąc tego rodzaju aluzje narrator wprowadza do swojej wypowiedzi element myślenia mitologicznego: wprowadza aspekt odkrywania przez protagonistę swojej niezafałszowanej tożsamości, obecny zarówno 
w wielkich mitach kultury, jak i podaniach ludowych. Owo odkrycie własnej tożsamości odbywa się zawsze we właściwym, to znaczy dopełnionym czasie i rozumiane jest jako ostateczne spełnienie się losu.

Zasadnicza służba wojskowa obudziła poczucie tożsamości narodowej Wiktora. Był to jeden z najważniejszych punktów zwrotnych w jego biografii: „w zasadzie po raz pierwszy poczułem się Białorusinem gdy skończyłem uniwersytet i trafiłem do wojska” [3:34-35]; „,no i tam oto po raz pierwszy jakoś powstało jakieś takie (3) poczucie (3) no narodziła się może pierwsze takie chwile poczucia białoruskości/ (3)" [3:46-47]. Służbę wojskową (która trwała półtora roku, w okresie 1982-1983) narrator odbywał w okręgu moskiewskim. Doświadczył pierwotnego poczucia przynależności, które pojawiło się w sytuacji zagrożenia: „((westchnienie)) no różne sytuacje były w wojsku i bardzo często to po prostu no tobie pomagali właśnie Białorusini a nie ktokolwiek inny $\backslash$ (3) tak\(.)" [3:48-49]. Sytuację w wojsku narrator opisuje ogólnikowo, wskazując na liczne trudności: „W wojsku tam po prostu życie wychowywało bo było stosunkowo ciężko jak to (.) z reguły bywa tam taki (.) okres przetrwania niejako i tu trzeba było liczyć na swoje własne siły głównie no i niewątpliwie było bardzo dobrze gdy ktoś udzielił wsparcia a wsparcia udzielali przeważnie swoi\ (2)" [4:4-8]. Wiktor niechętnie mówi o służbie wojskowej, używając przy tym eufemizmów takich jak „życie wychowywało”, prawdopodobnie zapożyczonych z nowomowy maskującej przemoc wojskowej pedagogiki. Można jedynie wnioskować, że służba wojskowa była doświadczeniem bolesnym, unieważniającym wszelkie inne więzi społeczne poza pierwotnymi więziami opartymi na wspólnocie ziemi i krwi. Służba w wojsku paradoksalnie wytwarzała podziały etniczne wśród żołnierzy. Narrator pokazuje konstytutywną dla procesów kształtowania się tożsamości siłę pozycji „swój”-,,obcy”. Rekruci wspierali się nawzajem w ramach „ziomkostw”: „w wojsku\ odbywałem służbę pod Moskwą moskiewska moskiewski okręg wojskowy $\backslash$ były tam takie u nas zgrupowania czy zrzeszenia czy powiedzmy ziomkostwa $\backslash$ (.) ukraińskie czy chachły ${ }^{8} \backslash$ białoruskie lub bulbaszami ${ }^{9}$ byli zwani zwykle (.) byli Kazachowie $\backslash$ byli tam Czeczeni \" [3:42-45]. Za pomocą odwołujących się do obecnych w społecznym obiegu stereotypowych atrybucji definiowano „innego" oraz rozpoznawano „swojego”: „bo skąd jesteś z Białorusi i już powiedzmy chachły od razu mieli odpowiednie nastawienie tam i a właśnie Białorusin znaczy się swój” [4:1-2].

Po zakończeniu zasadniczej służby wojskowej w 1983 r. Wiktor otrzymał posadę nauczyciela historii w miejskiej szkole średniej. Poza osobistymi doświadczeniami wyniesionymi z wojska i pogłębianą wiedzą historyczną kolejnym katalizatorem nabywania tożsamości narodowej stał się okres odwilży

\footnotetext{
8 Chachot — „kita, czub”, pejoratywne określenie Ukraińców, prawdopodobnie od tradycyjnej kozackiej fryzury.

9 Bulbaszy - „pyry”, pejoratywne określenie Białorusinów, prawdopodobnie od tradycyjnie uprawianego na Białorusi ziemniaka, który stanowi podstawę białoruskiej kuchni.
} 
w Związku Radzieckim: „tym bardziej że rok osiemdziesiąty trzeci już no przemiany się jeszcze nie odbywały w Związku Radzieckim ale coś już w powietrzu wisiało \" [4:12-14]. Doszło w tym czasie do kolejnego punktu zwrotnego w biografii narratora. W czasie zjazdu absolwentów wydziału historycznego Wiktor nieoczekiwanie - dla innych, a przede wszystkim dla siebie samego — zajął stanowisko "przekonanego nacjonalisty białoruskiego" [4:20] w sporze o znaczenie dumy narodowej, tym samym wyraźnie deklarując białoruską tożsamość.

Wiktor nakreśla kolejne znaczące miejsca i osoby, które sprzyjały krystalizacji jego świadomości narodowej. W osiemdziesiątym szóstym roku zaczął uczęszczać na spotkania w białoruskim ośrodku kulturalno-oświatowym Pochodnia ${ }^{10}$, zrzeszającym miejską inteligencję. Jako historyk Wiktor ocenia trafność hipotez narodowościowych stawianych w Pochodni przez znawców białoruskiej kultury i historii. Za niewiarygodną uznaje na przykład skrajnie białoruskocentryczną wersję historiografii Mikoły Jermałowicza ${ }^{11}$, który dowodzi między innymi, że Wielkie Księstwo Litewskie powstało wskutek zwycięskich walk Białorusinów, którzy podbili ziemie litewskie (ówczesnej Żmudzi), a nie odwrotnie [4:31-4:36]. Korzystając z typologii Krzysztofa Pomiana (2006), można stwierdzić, że narrator zarzuca Jermałowiczowi uprawianie historii rewizjonistycznej (zbudowanej na kanwie pamięci zwyciężonych), będącej przeciwieństwem równie nieobiektywnej historii urzędowej (reprezentującej pamięć zwycięzców), zamiast historii krytycznej, znajdującej się „na zewnątrz wszelkich nastawień tożsamościowych" (Pomian 2006, s. 80).

Powracając do wątku kariery zawodowej jako „konstrukcji w tle”, Wiktor zdawkowo i niezbyt chętnie podsumowuje swój powrót do pracy nauczyciela historii w szkole. Uważa to za okres niezbyt istotny z punktu widzenia przebiegu życia zawodowego czy osobistego. Twierdzi, że głównie trzymał się programu nauczania i najwyżej czynił odstępstwa od ogólnie obowiązującej wykładni, gdy komentował wydarzenia $z$ historii XX wieku. Jako godny uwagi natomiast przytacza incydent zaistniały pod koniec lat osiemdziesiątych, kiedy stanął w obronie uczniów starszych klas szkoły średniej noszących białoruskie symbole. Uczniowie zostali oskarżeni przez dyrektorkę szkoły o przejawy nacjonalizmu. Wiktor stanął w tym konflikcie w obronie uczniów [5:2-5].

Około 1985 r. Wiktor podjął pracę w Muzeum Historii i Religii w Grodnie. Praca ta zaowocowała nowymi znajomościami z artystami, będącymi jednocze-

10 Pochodnia — ośrodek kulturalno-oświatowy założony w Grodnie w marcu 1986 r. przez grodzieńskich miłośników kultury i historii o poglądach patriotyczno-narodowościowych, klub dyskusyjny, oaza względnej wolności, pozwalająca na wymianę poglądów na tematy wówczas drażliwe. W czasie spotkań czytano białoruską poezję i prozę, dyskutowano na tematy historyczne i polityczne.

${ }^{11}$ M. I. Jermałowicz, Pa sladach adnago mifa, Minsk 1989; M. Jermałowicz, Staražytnaja Biełarus'. Połacki i nowogarodski pieryady, Minsk 1990; M. Jermałowicz, Staražytnaja Biełarus'. Wilenski pieryad, Minsk 1994. 
śnie świadomymi Białorusinami. Doświadczenie to narrator określa w sposób następujący: „to było pierwsze takie no pierwsze spotkanie już z przedstawicielami no nowej inteligencji białoruskiej\” [4:40-42]. Szczególnie silne wrażenie wywarł na Wiktorze pewien konserwator zabytków, który „wtedy też rozmawiał już po białorusku/ tak a jego prace jego takie (.) zamiłowanie do historii białoruskiej to wywarło na mnie wielkie wrażenie\(.)" [4:43-4:45]. Narrator zamyka tę część narracji, ujmując proces „wychowania Białorusina” [5:9-10] w kategorie stopniowej i powolnej ewolucji poglądów w kierunku kształtowania się białoruskiej tożsamości.

Ważnym wydarzeniem, które przyspieszyło krystalizację tożsamości narodowej Wiktora, stały się rozpoczęte w 1990 r. studia doktoranckie w Instytucie Historii Akademii Nauk w Mińsku. Wiązało się to ze zmianą środowiska naukowego, zetknięciem się $z$ „historykami mińskimi historykami przy czym historykami naukowcami a nie dydaktykami a to zupełnie inna kategoria" [5:18-19]. Obcowanie z niezależnie myślącą białoruską elitą naukową oraz rozpad Związku Radzieckiego stały się katalizatorem przemian świadomościowych narratora. Wiktor zaczął też wykazywać większą inicjatywę w szkolnej pracy dydaktycznej (doktorat pisał zaocznie, pracując jednocześnie w szkole), a mianowicie był pomysłodawcą i realizatorem idei stworzenia szkolnego Muzeum Historii Edukacji i Kultury na Białorusi. Jak sam twierdzi, był to pomysł „nowatorski w tamtym czasie, bo zazwyczaj muzea tworzono w oparciu o taki materiał wojenno-patriotyczny, podczas gdy tu chodziło o pokazanie po prostu historii edukacji historii kultury Białorusi, no i powiązanie tego $z$ historią szkoły, z historią szkolnictwa w Harodni ${ }^{12}$ (...) tam już niewątpliwie obecna była powiedzmy taka historia białoruska w ujęciu narodowym" [5:24-5:27].

W 1993 r. Wiktor zmienił pracę, a wraz z nią — język wykładowy. Kontynuując pisanie rozprawy doktorskiej, zaczął wykładać w Instytucie Doskonalenia Zawodowego Nauczycieli, już w języku białoruskim. W 1995 r. przeszedł na język białoruski jako język użytku codziennego. To ostatnie postanowienie było wyrazem obywatelskiego nieposłuszeństwa $\mathrm{w}$ odpowiedzi na tak zwane referendum majowe ${ }^{13}$, w wyniku którego na Białorusi przywrócono radziecką symbolikę państwową, a językowi rosyjskiemu nadano status języka urzędowego. „Przejście na język białoruski jako język codzienny był to pewnie taki pewien (.) no etap już zwieńczenie kształtowania się tej białoruskiej świadomości narodowej\" [5:38-5:40].

Abstrahując od swoich osobistych wyborów, Wiktor dokonuje oceny roli języka w kraju i z przykrością stwierdza, że na Białorusi „język jednak mimo

12 Harodnia - białoruska nazwa Grodna.

13 Ogólnobiałoruskie referendum z 1995 r. zawierało pytanie „Czy zgadzasz się, aby język rosyjski miał równy status z językiem białoruskim?”, na które $83,1 \%$ respondentów odpowiedziało twierdząco. W wyniku referendum wprowadzono zmiany do „Ustawy o języku” z 1990 r., przywracając tym samym stan dominacji języka rosyjskiego jako języka urzędowego. 
całej doniosłości roli języka nie odgrywa może głównej wiodącej dziś roli\ " [5:42-43]. Zdaniem narratora, należy odstąpić od ambicji tworzenia silnego państwa narodowego i skupić się na realizacji idei państwowości w znaczeniu politycznym [5:46], „czyli nie etnicznie/ nie jako grupy etnicznej $\backslash$ nie całości etniczno-kulturowej (...) a formacji politycznej gdzie głównym kryterium przynależności do narodu białoruskiego będzie po prostu poczucie że Białoruś to twoja ojczyzna, że zamierzasz tu mieszkać, że tu będą mieszkać twoje dzieci, że wiążesz swoje życie $z$ tą ziemią\ " [5:46-49]. Wnioski te Wiktor wyciąga $z$ doświadczenia niepowodzenia polityki BNF (Białoruskiego Frontu Ludowego) na początku lat dziewięćdziesiątych, kiedy rygorystyczna polityka językowa zniechęciła Białorusinów do haseł narodowościowych. Zdaniem narratora, „tę narodową ideologię trzeba łączyć z jakimś bardzo popularnym politycznym programem czy jakimiś nośnymi politycznymi czy społeczno-politycznymi hasłami ” [6:4-6:6], żeby zyskać masowe poparcie obywateli.

Ilustrując swoją tezę, Wiktor przytacza przykład badań terenowych na pograniczu Polski, Białorusi i Litwy, w których brał udział w 1999 r. Jak się okazało, przeważnie białoruskojęzyczna ludność wschodniego okręgu wileńskiego deklaruje polską identyfikację narodową. Narrator opowiada: „nawet pewnego razu (...) sprowokowałem ich tak z ciekawości (...) co z was za Polacy mówię przecież rozmawiacie po białorusku/ mieszkacie na Litwie obywatelstwo macie litewskie języka polskiego nie znacie co z was za Polacy/" [6:16-6:18], na co zdezorientowany respondent odpowiedział z przekonaniem: ,jestem narodowości polskiej\(.)" [6:21-22]. Próbując wytłumaczyć fenomen braku spójności między używanym językiem, obywatelstwem i przynależnością narodową respondentów, Wiktor powołuje się na tradycyjne utożsamianie katolickiego wyznania z polską narodowością. Na Wileńszczyźnie językiem liturgii w Kościele katolickim jest język polski i litewski, język białoruski ma natomiast status języka powszedniego i prywatnego, jest „mową prostą $\backslash$ tak jak sto lat temu ”. Narrator konkluduje: „(.) stąd brak utożsamiania się z białoruskością". Wiktor podsumowuje, że udział w przytoczonych badaniach terenowych podważył jego dotychczasowe przekonania o tym, że język jest podstawowym wyznacznikiem tożsamości narodowej — jako „podstawa kultury” [6:34] — w przypadku mieszkańców wschodniego okręgu wileńskiego „język istnieje niezależnie, osobno, obok tożsamości narodowej" [6:34-35].

Jak widać, opowiedziana historia życia narratora jest strukturalizowana wokół jego przemian świadomościowych, umiejscowionych na kontinuum od tożsamości radzieckiej do białoruskiej tożsamości narodowej. Uważna lektura narracji Wiktora odsłania wyraźny związek między procesami makrospołecznymi a poszczególnymi sekwencjami relacjonowanego przebiegu życia narratora. Nie bez znaczenia jest fakt, że lata przełomu i względnej demokratyzacji (1985-1995) przypadły na okres ważnych decyzji życiowych i zawodowych narratora, który właśnie w tym okresie wkraczał w dorosłe życie. Okres pierestrojki zainicjowanej przez Michaiła Gorbaczowa w 1985 r. aż do odzyskania przez Białoruś 
niepodległości w 1991 r., jak również lata poprzedzające objęcie urzędu prezydenta przez Aleksandra Łukaszenkę w 1994 r. to dla Białorusi dekada względnej wolności słowa, poszukiwania i wyłaniania się nowych partii i liderów, poszukiwania własnej drogi rozwoju kraju, optymalnego ustroju politycznego, systemu ekonomicznego i rozstrzygnięcia innych istotnych kwestii makrospołecznych. W tym właśnie okresie dokonuje się odsłonięcie, kształtowanie i pełna krystalizacja białoruskiej tożsamości narratora. Procesowi temu towarzyszą punkty zwrotne w biografii, pojawiają się „znaczący inni” przyspieszający proces samoidentyfikacji, narrator odnajduje grupę odniesienia przypominającą dziewiętnastowieczne kręgi czy kółka inteligenckie. Podobnie jak inni świadomi Białorusini, Wiktor nadal trwa $\mathrm{w}$ akcie obywatelskiego nieposłuszeństwa, na przekór rządowej polityce rusyfikacji na co dzień używając ojczystego języka.

Żona Wiktora, „białoruska patriotka” [13:25], na co dzień mówi po rosyjsku, choć „jeśli dzwonią powiedzmy moi przyjaciele zdarza jej się odpowiedzieć po białorusku” [13:25-26]. Co za tym idzie, Wiktor „w domu rozmawia $z$ nimi [dziećmi] po białorusku $\backslash a$ one ze mną po rosyjsku\ " [13:30-31], „choć starsza chodzi do białoruskiej klasy ale nawet w białoruskiej klasie dzieci nie mają w zwyczaju rozmawiać w swoim towarzystwie po białorusku" [13:26-28]. Starsza córka czasami pisze do ojca listy po białorusku w czasie wyjazdów [13:29-30]. Córki obiecują, że „gdy dorosną będą mówiły wyłącznie po białorusku" [13:37-38].

\section{PRZYPADEK LAWONA}

Dla Lawona, w odróżnieniu od Wiktora, środowisko rodzinne stanowiło źródło białoruskiej samoidentyfikacji i znajomości języka ojczystego: „znacznie wcześniej niż doszedłem do uświadomienia sobie znaczenia języka białoruskiego czy znaczenia historii czy jeszcze czegoś/ po prostu żyłem w pewnym środowisku/" [3:3-5]. Rodzice urodzonego w Mińsku w 1956 r. narratora z zawodu byli dziennikarzami: matka pracowała w białoruskiej telewizji, ojciec - w białoruskiej gazecie. W środowisku pracy rodziców panowała dwujęzyczność, z tym że znajomość języka białoruskiego była koniecznością. Przechodzenie $z$ języka rosyjskiego na białoruski i odwrotnie od dziecka było dla Lawona czymś zupełnie naturalnym: „potem nie było żadnych problemów/ tak i obecnie $z$ przejściem $z$ jednego języka na drugi $\backslash w$ tym środowisku językowym ponieważ wszyscy poważnie traktowali język białoruski\nawet ci mówiący po rosyjsku" [9:28-31].

Rodzice Lawona zajmowali wobec ustroju komunistycznego postawę nonkonformistyczną. Ojciec narratora nigdy nie wstąpił do partii komunistycznej. Wszyscy się dziwili: „jak możesz być redaktorem działu [czasopisma] nie będąc członkiem partii/" [11:17]. Dwupokojowe mieszkanie rodziców Lawona, zawsze pełne gości, było popularnym miejscem spotkań znajomych ze studiów i redakcji, literatów, przedstawicieli świata kina, filozofów, jednym słowem, 
„ciekawych osobistości” [11:9]. W dużej mierze spotkania te kształtowały światopogląd młodego człowieka: „oczywiście to także miało na mnie wpływ w tym sensie że ci ludzie często nas odwiedzali" [9:9-11]. W czasie tych spotkań prowadzono „dosyć szczere/ zbyt szczere rozmowy głównie polityczne” [9:25-26]. Szczerość tych rozmów odcisnęła piętno na karierze zawodowej rodziców Lawona, ponieważ wśród stałych gości „znalazł się kapuś który doniósł na nich do KGB/ nie tylko doniósł nagrywał na taśmẹ" [11:12-13]. W wyniku donosu ojciec narratora stracił pracę, był przesłuchiwany przez KGB i cudem uniknął więzienia. Matce zaproponowano, by sama złożyła wymówienie i uniknęła tym samym przesłuchań oraz innych przykrych konsekwencji. Po jakimś czasie udało się jej znaleźć pracę w państwowej placówce naukowej. Ojciec natomiast przez wiele lat był zmuszony pracować w domu, zarabiał głównie jako tłumacz.

Kilkakrotnie $\mathrm{w}$ wywiadzie narrator podkreśla rolę rodziców w procesie kształtowania się jego białoruskiej tożsamości narodowej. Świadczy o tym chociażby poniższy incydent, który stał się punktem zwrotnym w biografii Lawona. Mianowicie w wieku osiemnastu lat Lawon otrzymał od rodziców lekcję życia przy okazji deklarowania swojej narodowości w biurze paszportowym. Osoba otrzymująca dokument musiała podać do wpisania narodowość ojca lub matki. Lawon dokonał najbardziej oczywistego wówczas wyboru: podał narodowość rosyjską (po ojcu). Na wieść o tym rodzice urządzili mu ogromną karczemną awanturę: „powiedzieli jak mogłeś/ wyparłeś się matczynej mowy/ jak mogłeś powiedzieć że nie jesteś Białorusinem" [6:23-25]. Po raz pierwszy wprowadzili wówczas syna w tajniki pochodzenia etnicznego jego ojca i dziadków ze strony ojca. Wyjaśnili, że babcia Lawona ze strony ojca była na wpół Polką na wpół Rosjanką, dziadek zaś był Żydem, zapisanym w dokumentach jako Rosjanin, żeby uniknąć problemów w czasie wojny. Matka Lawona natomiast jest z pochodzenia Białorusinką. Pod naciskiem rodziców narrator wrócił do biura paszportowego, aby zmienić zapis: „i tak mnie zawstydzili że wróciłem tam i zebrałem całą swoją odwagę tak mi się strasznie nie chciało nienawidzę mieć do czynienia $z$ tymi gryzipiórkami ale poszedłem tam i powiedziałem że tak naprawdę jestem Białorusinem $\backslash$ i zapisali że jestem Białorusinem\” [6:26-29].

Opisany incydent stał się dla narratora impulsem do rozważań na temat własnej tożsamości: „zmusiło mnie to do zastanowienia kim i czym jestem\” [6:30-31]. Po tym wydarzeniu Lawon nadal na co dzień rozmawiał po rosyjsku, nie widząc w tym niczego zdrożnego: „co z tego wszyscy mówili po rosyjsku\" [6:33-34]. Studiował wówczas biologię, ale dojrzewał do decyzji, by - podobnie jak rodzice - zostać dziennikarzem (mimo kategorycznego sprzeciwu ze strony obojga). Ostatecznie przerwał studia na wydziale biologii i dostał się na wieczorowe dziennikarstwo. Na wydziale dziennikarstwa wielkie wrażenie na narratorze wywarł wykładowca języka białoruskiego Mikoła Ryhorawicz Kawalenka, który miał „dar od Boga” [10:17] i zaszczepił mu miłość do języka ojczystego. Na tej samej uczelni narrator poznał kolejną osobę znaczącą z punktu widzenia własnej tożsamości narodowej - Mikitę Nowa- 
$\mathrm{ka}^{14}$, również studenta dziennikarstwa: „jestem przekonany że podstawową rolę odegrali rodzice a kolejną właśnie Mikita Nowak/" [7:11-12]. Mikita, który pozostał przyjacielem narratora na całe życie, „zaczął tłumaczyć że jesteśmy Białorusinami zaczął przynosić publikacje/ wydania które zresztą wychodziły jeszcze przed wojną na Litwie/ w języku białoruskim różne takie ciekawe rzeczy/" [7:20-22]. W ocenie narratora Mikita był osobą charyzmatyczną i gdy zaczął rozmawiać po białorusku, wielu, w tym Lawonowi, to zaimponowało.

Wspólnie z przyjaciółmi narrator zaczął rozmawiać po białorusku, głównie „z chęci zamanifestowania opozycyjności/ niezadowolenia wobec istniejącego rządu czy ładu/" [7:23-24]. Wraz ze swoją grupą odniesienia narrator z wielką satysfakcją manifestował swoją białoruskość, na przykład rozmawiając w swoim ojczystym języku w środkach transportu publicznego: „nagle się okazało że można być opozycjonistą po prostu rozmawiając po białorusku i korzystaliśmy $z$ tego i tak z uczuciem rozmawialiśmy w transporcie/" [7:27-29]. Narrator konstatuje, że ostentacyjne mówienie po białorusku było wśród „świadomej” młodzieży swoistą modą, której niestety współczesna młodzież nie kontynuuje [7:29-34].

Istniały też bardziej zorganizowane formy zaznaczania swojej białoruskości, na przykład kółka i stowarzyszenia o charakterze narodowościowym. Wspólnie $z$ innymi świadomymi Białorusinami Lawon uczęszczał na próby chóru ludowego (choć „strasznie nie lubiłem śpiewu/ nie miałem ani słuchu ani głosu/” [7:37]). W czasie tych spotkań poznał wielu znanych obecnie działaczy białoruskich, na przykład późniejszych liderów partii BNF Wincuka Wiaczorkę i Wiktara Iwaszkiewicza. Spotkania chóru ludowego przekształciły się w 1986 r. $\mathrm{w}$ znany na Białorusi ruch młodzieżowy Tałaka ${ }^{15}$. Właśnie poznani $\mathrm{w}$ tym środowisku działacze rozpowszechniali literaturę drugiego obiegu, „zajmowali się taką pracą u podstaw/ takie broszury" [9:47]. Dzięki liderom białoruskiego środowiska młodzieżowego, takim jak Wincuk Wiaczorka i ,jemu podobnym [...] dowiedziałem się co to biało-czerwono-biała flaga (.) co to Pahonia 16/ takie podstawowe rzeczy" [9:45-46]. Z regularnych spotkań środowiska inteligenckiego u rodziców wyniósł na przykład wrażenie, że zachowanie rosyjskojęzycznych literatów było bardziej kulturalne, imponujące niż zachowanie białoruskojęzycznych pisarzy, „wiejskich mało kulturalnych chłopów” [9:36]. Przyswajając literaturę białoruską, narrator przede wszystkim zwracał się ku prozie i poezji zakazanej (na przykład publicystyce Antona Łuckiewicza), a krytycznie odnosił się do dzieł współczesnych twórców białoruskich (na przykład

\footnotetext{
14 Znany działacz. Imię i nazwisko zmienione.

15 Tałaka — jedna z pierwszych nieformalnych organizacji pozarządowych na Białorusi, zajmująca się między innymi popularyzacją białoruskiej kultury ludowej i ratowaniem zabytków.

16 Autor ma na myśli obecnie zakazaną białoruską symbolikę, biało-czerwono-białą flagę i godło Pahonia.
} 
Bykaua czy Karatkiewicza). Dotarcie do tych źródeł w latach osiemdziesiątych zapewniało właśnie środowisko zbuntowanej młodzieży białoruskiej.

Po pewnym czasie Lawon przestał jednak regularnie uczestniczyć w spotkaniach ośrodków białoruskich, ponieważ — według własnej oceny — jest „kotem który chodzi własnymi drogami" [8:3]. Zawarte wówczas przyjaźnie przetrwały jednak do końca życia ${ }^{17}$, a narrator został cenionym niezależnym dziennikarzem i pisarzem. Podsumowując wątek odkrywania i krystalizacji swojej tożsamości narodowej, Lawon konstatuje, że poza samokształceniem także czynniki środowiskowe odegrały dużą rolę: „takie proste rzeczy mianowicie rodzice/ nauczyli że jesteś Białorusinem a nie Rosjaninem\wykładowca który zaszczepił miłość do języka białoruskiego/i wreszcie przyjaciele $\backslash[. .$.$] a następnie docho-$ dzi do bardziej głębokiego uświadomienia sobie jak bardzo cierpiał ten naród i rozkułaczenie i wojna/ i te wszystkie koszmary po wojnie \" [10:17-22].

Lawon z żoną postanowili nie narzucać swojemu synowi wyboru języka i tożsamości, licząc na to, że sam do tego dojrzeje: „i dojrzał do języka białoruskiego \jest po prostu fanatykiem \znacznie bardziej zdecydowanym wyznawcą białoruskości/" [12:3-5]. Na przykład bardzo się denerwuje, kiedy jego ojciec zaczyna rozmawiać z żoną po rosyjsku, która - jak wspomina narrator „kiedy poznaliśmy się zupełnie nie mówiła po białorusku” [12:11]. Zaczęła mówić po białorusku dzięki przyjacielowi Lawona, Mikicie Nowakowi, który ją ciągle zawstydzał, aż „pewnego razu zaczęła mówić po białorusku” [12:15-16] w towarzystwie „chłopaków” [12:16] z redakcji, w której wówczas pracował narrator. Można zatem skonstatować, że Lawon kontynuuje tradycję swoich rodziców w krzewieniu białoruskości i prowadzeniu domu otwartego dla nonkonformistycznej inteligencji.

\section{PRZYPADEK ALESI}

Czasy drugiej wojny światowej, poza sprzecznymi interpretacjami okresu władzy radzieckiej, w tym represji stalinowskich, kolektywizacji i rusyfikacji Białorusi, stanowią kluczowy element narodowej martyrologii, są przy tym źródłem sprzecznych interpretacji mitu wyzwoleńczej Armii Czerwonej. Właśnie kwestię cierpienia narodu białoruskiego z perspektywy zaangażowania eksploruje urodzona w 1949 r. Alesia, która - jako Białorusinka - czuje się odosobniona wśród rzeszy rodaków o niskim poziomie świadomości narodowej i ambiwalentnej tożsamości: „i tak się zrodziła moja samoświadomość narodowa/ która w zasadzie ((śmiech)) nie ma teraz żadnego ujścia \" [4:40-41]. Przedstawiona niżej narracja pochodzi od osoby, która nie znalazła dla siebie białoruskojęzycznej grupy odniesienia i swoją tożsamość buduje na wzór tożsamości negatywnej (postimperialnej), opartej na odrzuceniu rosyjskości.

$17 \mathrm{~W}$ chwili pisania artykułu narrator już nie żyje. 
W wywiadzie z Alesią zwraca uwagę przede wszystkim specyficzna strategia narracyjna, polegająca na przedstawianiu własnej grupy etnicznej jako ofiary innych grup, a także społecznych i historycznych procesów. Narracyjny topos „bycia ofiarą” 18 jest przy tym używany jako szczególny rodzaj zasobu, który wyznacza oś heurezy w praktykach refleksyjnego odnoszenia się do własnej biografii. Jak pokazuje wywiad, narratorka w ramach swojej społeczności lokalnej przyjmuje rolę demaskatora cudzych i własnych słabości (por. Strauss 1975; Riemann, Schütze 1992). Między innymi wielokrotnie krytykuje i demaskuje ukryte motywy działania dominującej (w różnych okresach historycznych) polskiej i rosyjskiej grupy etnicznej, a także samych Białorusinów.

Narratorka ma żal do rodaków, między innymi o to, że nie czczą swoich poległych $w$ walce $z$ sowieckim reżimem, $w$ tym wielu tysięcy (według różnych szacunków od 30 do 250 tys.) osób zamordowanych w Kuropatach ${ }^{19}$ z rąk NKWD i spoczywających w zbiorowych mogiłach: „naród który [...] nie potrafi z nazwiska wymienić swoich zabitych" (4:41-43). Białorusini nie znają także swoich radzieckich oprawców, stawiają im pomniki i upamiętniają ich w nazwach ulic: „naród który nie potrafi wymienić/ (.) z nazwiska swoich katów $\backslash[. .$.$] naród który się godzi na ulicę siedemnastego września \(2) w tym$ dniu w trzydziestym dziewiątym wkroczyły tu wojska bolszewickie $\backslash$ (2) nie na promenadę przecież $\backslash$ (.) strzelali do miejscowych\" [4:41-49]. Przy tej okazji Polska zostaje także częściowo obarczona winą za oddanie się Białorusinów w bolszewicką niewolę. Narratorka sugeruje, że białoruskie chłopstwo, marząc o wyzwoleniu się spod jarzma "polskich panów”, dało się porwać komunistycznym sloganom: „ale Białorusini obdartusy/ witali ich z otwartymi ramionami widzieli w nich swoich \być może częściowo dlatego że Polacy (.) doprowadzili do tego że byliśmy ze wszystkiego obdarci〉" [4:49-5:1].

Sama Alesia przejrzała na oczy, jak twierdzi, dopiero w czasach pierestrojki, po ukończeniu 35 lat. Narratorka obrazowo opisuje symboliczny moment przebudzenia, kiedy to odważyła się zareagować na deprecjonującą Białorusinów uwagę: „pamiętam stoję w kolejce i jakiś kombatant mówi myśmy was wyzwolili $\backslash \mathrm{i}$ nagle sobie przypomniałam\ (.) że mój tata (.) w wieku lat dziewiętnastu kiedy wkroczyły tu wojska radzieckie \został wysłany na front $\backslash$

18 Szerzej i w nieco innym kontekście zob. Krakowiak, Mamul 2008.

19 Kuropaty - las na przedmieściach Mińska, miejsce rozstrzelania ofiar stalinowskich represji w latach 1937-1941 na Białorusi. „W lesie w pobliżu wsi Kuropaty koło Mińska w 510 mogiłach pochodzących $z$ lat 1937-1938 według szacunków archeologicznych mogło zostać pochowanych ponad 100 tys. osób" (Mironowicz 2007, s. 94). Podanie do publicznej wiadomości (m.in. przez Zianona Paźniaka) informacji o mordzie w Kuropatach i ekshumacja zwłok przeprowadzona w $1988 \mathrm{r}$. stały się ważnym impulsem powstania niepodległościowego ruchu na Białorusi. Lasy Kuropackie są ważnym symbolem praktyk upamiętniających (miejscem spotkań sił demokratycznych i opozycji). Ponieważ represje stalinowskie stanowią kluczowy obszar sporny, spotkania wokół masowych grobów w Kuropatach często kończą się starciem z policją porządkową (por. Pankowiec 2007). 
i dosłownie cztery miesiące później/ na terenie Polski/ (.) stracił prawą nogę\ jest inwalidą drugiej grupy i ostatecznie miał protezę a początkowo poruszał się o kulach/ (.) dzień zwycięstwa zastał go we Lwowie w szpitalu polowym\ urwało mu część prawego ramienia \ma olbrzymie ubytki na plecach generalnie ledwo uszedł $\mathrm{z}$ życiem $\backslash \mathrm{w}$ gipsie przeleżał kilka miesięcy $\backslash$ ten gips był cały zarobaczony $\backslash$ pielęgnia:rka go doglądała:/ ostatecznie przeżył i nagle mówię temu kombatantowi nagle to sobie przypomniałam/ a propos broni rosyjskiej i rosyjskiego zwycięstwa i mówię mu wie pan co ja osobiście zostałam wyzwolona przez swojego własnego ojca \narodowości białoruskiej (2) i osobiście stracił tam/ swoją własną prawą nogę (.) a co się tyczy tego żeście to wy nas wyzwolili przepraszam bardzo ale wyzwoliciele wyzwalają i odchodzą \" [3:17-31].

Wypowiedź Alesi jest przekroczeniem panujących w polu lokalnej polityki reguł poprawności, wykroczeniem przeciw panującym regułom dyskursu. Według Krzysztofa Pomiana (2006, s. 78-79), w opisanej sytuacji dochodzi do zderzenia utrwalonej w postaci „historii urzędowej” "pamięci zwycięzców” (w osobie rosyjskiego kombatanta) z „pamięcią zwyciężonych" (w osobie narratorki) ${ }^{20}$, czyli "pamięcią prywatną i mało widzialną, o ile nie jest ona wręcz ukryta i udostępniana tylko wtajemniczonym”. Narratorka „nagle sobie przypomniała" cierpienie i inwalidztwo własnego ojca, który — podobnie jak wielu białoruskich chłopców z zajętych przez Armię Czerwoną terenów - w czasie drugiej wojny światowej został wykorzystany przez ZSSR jako mięso armatnie. Po wojnie rola walczących i poległych nie-Rosjan w osiągnięciu zwycięstwa została zmarginalizowana przez radziecką propagandę i historiografię: „wojnę wygrali Rosjanie/ ofiarami byli głównie Rosjanie \i w ogóle Rosja to znaczy Rosja i Rosjanie w wojnie zwyciężyli`" [3:9-11].

Alesia odsłania swój habitus Białorusinki, snuje rozważania na temat ukrytego i długotrwałego procesu indoktrynacji radzieckiej, który zmieniał umysły Białorusinów: „nawet nie to żeby to było narzucane $\backslash$ to się działo w sposób niezauważalny/ jak gdyby jakieś ciało obce przedostawało się wszystkimi porami/ nikt nie mówił że Rosjanie są lepsi nie \po prostu wojnę wygrali Rosjanie/ ofiarami byli głównie Rosjanie \i w ogóle Rosja to znaczy Rosja i Rosjanie w wojnie zwyciężyli\" [3:7-11]. Narratorka ujawnia oddziaływanie przemocy symbolicznej i strukturalnej (w tym polityki rusyfikacji), która okazuje się tak skuteczna i wszechobecna - „przedostaje się wszystkimi porami” [3:8] - że prowadzi do zmiany rudymentarnych dyspozycji Białorusinów. Moment, w którym narratorka odważyła się publicznie zakwestionować wpajaną odgórnie "prawdę"

20 „Są zatem [...] zwycięzcy i zwyciężeni. Znaczy to, że są też dwie nie dające się pogodzić pamięci: pamięć zwycięzców i pamięć zwyciężonych. Obie te pamięci utrwalają się, przechodzą jedna obok drugiej z pokolenia na pokolenie, przeciwstawiają się sobie i pospołu utrzymują między swymi nosicielami stan wrogości lub zgoła nienawiści. Odtwarzają przeto wciąż na nowo pierwotny konflikt, który przedłużają przy pomocy słów, obrazów i relikwii” (Pomian 2006, s. 78). 
o wyzwoleniu Białorusi przez Armię Czerwoną, stał się chwilą objawienia. Nazywając rzeczy po imieniu, Związek Radziecki nie wyzwolił, lecz okupował Białoruś: „(.) a co się tyczy tego żeście to wy nas wyzwolili przepraszam bardzo ale wyzwoliciele wyzwalają i odchodzą\" [3:31].

Procesowi dekonstrukcji zakorzenionych w świadomości relacji centrum-peryferie (por. Furman 1999) towarzyszy postimperialny sposób pamiętania, który „nigdy nie jest spokojnym aktem introspekcji czy retrospekcji. Jest to bolesne rozpamiętywanie, układanie na nowo strzępów przeszłości, by poradzić sobie z traumą teraźniejszości" (Bhabha 2010, s. 63). Wśród pewnej grupy Białorusinów strategia „bycia ofiarą” stanowi zinternalizowaną konwencję mówienia o własnej grupie, ponieważ na tym zasadza się ich negatywna tożsamość, w dużej mierze czerpiąca $z$ wyraźnych podziałów między grupą własną a jej oprawcami (w danym wypadku, historycznie, Rosjanami, Polakami, nazistami i Sowietami). Sprzeczne interpretacje przeszłości odpowiadające pamięci „zwycięzców”, której nośnikiem jest rosyjska grupa etniczna, i pamięci „zwyciężonych" (Pomian 2006), której nośnikiem jest białoruska grupa etniczna, w państwach dawnego bloku radzieckiego są zjawiskiem typowym (por. Jalusic 2007; Wertsch 2008). Jak twierdzi James V. Wertsch, korzystając z terminologii Vladimira Proppa, wątek „wydalenia obcych” głęboko zakorzenił się w dawnej radzieckiej i obecnej rosyjskiej pamięci zbiorowej: „Obok zastąpienia partii komunistycznej ludem rosyjskim jako bohaterem oficjalnych opowieści o drugiej wojnie światowej, istnieją inne przesłanki mówiące o tym, że narracyjny szablon "wygnania obcych" głęboko tkwi w rosyjskiej pamięci zbiorowej" (Wertsch 2008, s. 151) ${ }^{21}$.

Obalając rosyjski mit wyzwoleńczy, narratorka podważa fundament rosyjskiej metanarracji i, co za tym idzie, rosyjskiej pamięci i ostatecznie — „rosyjskiej tożsamości narodowej” (Wertsch 2008, s. 152). Bezwzględność odczłowieczonego zbiorowego rosyjskiego oprawcy jest zestawiona z przykładem jednostkowego cierpienia i odwagi, co przywraca białoruskiemu podmiotowi aktywny udział w zwycięstwie w drugiej wojnie światowej: „ja osobiście zostałam wyzwolona przez swojego własnego ojca \narodowości białoruskiej (2) i osobiście stracił tam/ swoją własną prawą nogę (.)" [3:28-29]. Przeciwstawienie sobie oprawcy i ofiary, „ich" i „nas”, stanowi budulec etnicznej i narodowej tożsamości narratorki: „a co się tyczy tego żeście to wy nas wyzwolili przepraszam bardzo ale wyzwoliciele wyzwalają i odchodzą $\backslash$ i to tyle \właśnie

21 Zauważmy, że wokół wątku „wydalenia obcych” zorganizowane jest nowe, wprowadzone w putinowskiej Rosji, święto Dnia Jedności Narodowej, które zastąpiło coroczne obchody rocznicy rewolucji październikowej. Święto to, obchodzone 4 listopada, upamiętnia kapitulację polskiej załogi moskiewskiego Kremla (7 listopada 1612 r.). Ustanowienie nowego święta propagandowo wzmocniono filmową superprodukcją zatytułowaną „,1612. Kroniki wielkiej smuty”, luźno nawiązującą do tego epizodu z wojny polsko-rosyjskiej 1609-1618. Ustanowienie nowego święta, a także nadanie mu atrakcyjnej filmowej, w istocie narracyjnej oprawy, pokazuje, jak propagandowo aktywizowane i wykorzystywane są obecne w społecznej pamięci toposy. 
tak no i w ogóle to było obraźliwe \to było jakieś obrzydliwe \" [3:31-32]. Zgodnie $z$ formułą „zbiorowego poczucia niewinności” (Jalusic 2007), podmiot białoruski ucieka się w stan niezaskarżalności (Korzeniewski 2006). Zastosowane przez narratorkę interpretacyjne ramy „zbiorowego poczucia niewinności" (Jalusic 2007) odzierają z cech ludzkich zarówno oprawcę, jak i ofiarę. Oprawca, któremu przypisana jest zbiorowa odpowiedzialność, jest demonizowany. Ofiara natomiast zostaje zmistyfikowana i oczyszczona ze wszystkich grzechów. Wzorzec „zbiorowego poczucia niewinności” pełni zatem podwójną funkcję: „z jednej strony, pozwala na bezmyślność, pomagając ludziom pozbyć się poczucia odpowiedzialności za swoje sądy, z drugiej zaś pomaga im zrzec się zdolności do działań, w ten sposób niszcząc zarówno osobiste, jak i zbiorowe (polityczne) poczucie odpowiedzialności" (Jalusic 2007, s. 1185).

Zarówno w przytoczonym fragmencie, jak i wielokrotnie w całym wywiadzie narratorka opisuje ZSRR i współczesną Rosję jako podmiot brutalny, zachłanny, stosujący przemoc wobec etnicznych innych. Alesia przywołuje praskie wydarzenia z 1968 r., „gdy wojska radzieckie weszły z czołgami/ (.)” [8:1]. Rosja, która przyswoiła sobie dokonania epoki radzieckiej, obciążona zostaje winą za popełnione na innych narodach zbrodnie sowieckie. Białorusinom przypisane zostaje miejsce po stronie ofiar, takich jak Czesi, którzy okazali się równie bezsilni w obliczu brutalnego i bezwzględnego napastnika. Klarowny podział na „ofiary” i „oprawców” służy wzmocnieniu podziałów na grupę „my” i „oni”, co przekłada się na silniejsze poczucie więzi wewnątrzgrupowej. Współczesna Rosja nadal realizuje swoje imperialistyczne zapędy: „i to nie myśmy dorwali

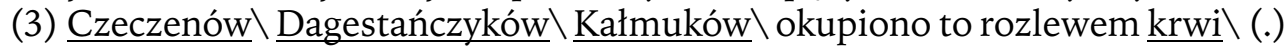
łzami \(2) cudzym nieszczęściem \a teraz co// tak w ogóle Rosję wyobrażam sobie teraz jako żarłocznego rekina który się tego wszystkiego nachapał a teraz krwią zwraca \(.)" [8:4-7]. Posługując się barwnymi porównaniami, narratorka demaskuje i przewiduje, demonizuje obraz wroga (por. Janion 2007) i przepowiada jego rychłą klęskę. Demonizacji i odczłowieczeniu obrazu oprawcy towarzyszy konstrukcja wyższości moralnej grupy własnej. Zabieg ten działa jako pewien „system moralizacji/ kultury etycznej, zgodnie z którą małe ludy czy niewielkie kraje nie mogą wziąć na swoje barki odpowiedzialności za własny los, ponieważ świat jest zdominowany przez wielkich i majętnych" (Donskis 1999, s. 351).

Mimo że w roku 1968, w czasie sowieckiej inwazji na Czechy, Białoruś wchodziła w skład ZSSR, Rosja jest obarczona całkowitą odpowiedzialnością za ten akt agresji: „ale w Pradze/ w sześćdziesiątym ósmym/ gdy wojska radzieckie weszły z czołgami/ (.) na murach widniały napisy nie po białorusku (2) żołnierzu (.) powiedz mamie że giną nasi było to napisane po rosyjsku" [7:50-8:3]. Innymi słowy, ,jednym z podstawowych cech syndromu zbiorowej niewinności są zbiorowe kłamstwa i odmowa uznania własnej winy przez zbiorowość narodową" (Jalusic 2007, s. 1181-1182). Co więcej, linia podziałów biegnie wzdłuż różnic językowych. Białoruś jest postawiona w jednym szeregu 
z Czechami, ofiarą rosyjskiej agresji. Jako osoba świadoma prawdziwego oblicza wroga Alesia jest rozgoryczona zaślepieniem swoich rodaków, którzy są nadal zapatrzeni $\mathrm{w}$ Rosję. W inscenizowanej rozmowie $\mathrm{z}$ uogólnionym prototypem zrusyfikowanego Białorusina o ambiwalentnej tożsamości narodowej Alesia przekonuje, że zjednoczenie $z$ Rosją będzie skutkowało jedynie instrumentalnym wykorzystaniem Białorusinów, w tym białoruskiej młodzieży, do realizacji imperialistycznych celów „wielkiego brata”: „pytam po co chcecie się $z$ taką Rosją jednoczyć/ (.) chcielibyście by wasi synowie wnuki zostali wysłani do kolejnego Dagestanu czy Czeczenii/" [8:10-12].

Białoruś, która „nigdy” nie była agresorem i napastnikiem, notorycznie staje się ofiarą opresji ze stronny innych, dominujących grup. Niezdolność do agresji wobec innych etnicznie jest pozytywnym wyznacznikiem białoruskiej tożsamości: „ukojenie znajduję w myśli że nigdy nikogo nie skrzywdziliśmy\ " [8:3-4]. Stawiając Białoruś w opozycji do zachłannej i brutalnej Rosji, narratorka podkreśla pokojowe nastawienie i bezbronność swojego kraju. Dzięki retrospekcji i pracy analitycznej nad przeszłością Alesia odsłania panującą w czasach radzieckich rosyjską hegemonię kulturową (termin Antonia Gramsciego). Wskazuje też mechanizmy przemocy symbolicznej skutecznie oddziałującej w ramach systemu edukacji i propagandy: „(.) jakoś tak już w szkole ciągle mówiono że wszystkiego dokonali Rosjanie \(.) w kosmos polecieli/ pierwsi ksiażke wydrukowali\" [7:43-44]. Narratorka podsumowuje sarkastycznie: „święta Rosja\wielka historia” [7:44], drwiąc z mitu „wyjątkowości Rosji na całym kontynencie euroazjatyckim" (Sidorov 2006, s. 317) oraz metafory Rosji jako „trzeciego Rzymu” lub „następcy imperium rzymskiego i Bizancjium [...] który przetrwał nawet epokę bolszewizmu" (Sidorov 2006, s. 317). Wraz z propagowaniem nadrzędności kultury i języka rosyjskiego, jak również rosyjskich dokonań (radzieckie dokonania stawały się tożsame z rosyjskimi), pomniejszano wartość kultury i języka narodowego poszczególnych republik radzieckich, dziś stanowiących byty niepodległe. W konsekwencji Białorusini zaczynali postrzegać swoją kulturę, język i dziedzictwo jako drugorzędne: „a my jesteśmy tacy maluczcy $\backslash$ (.) żadnych nie mamy dokonań $\backslash$ (.)" [7:44-45]. Prawomocnym stawało się przekonanie o byciu peryferią w stosunku do Moskwy jako centrum.

Uświadomienie sobie manipulacji dokonanych przez grupę dominującą ujawnia narratorce własny status bycia ofiarą zarówno przemocy symbolicznej, jak i społecznych oraz historycznych okoliczności. Obok potęgi militarnej rosyjskiego hegemona oraz jego zapędów imperialistycznych (środki przymusu) narratorka wskazuje rosyjski imperializm językowy i kulturowy (środki uwodzenia): „Można powiedzieć, że władza niweluje przepaść między przymusem a uwodzeniem, ukazując wiele zaskakujących oblicz. Urzeczywistnia się poprzez manifestację i użycie siły, a równie dobrze może pojawić się jako bezstronny nosiciel kaganka oświaty i reform. Przez tę podwójną reprezentację władza ustala zarówno granice polityczne, jak i horyzonty kulturowe" (Gandhi 
2003, s. 359). Alesia odsłania mechanizmy władzy grupy dominującej i rozpoczyna proces dekonstrukcji zależności centrum-peryferie, który ostatecznie unieważnia wpajany przez dominującą grupę obraz siebie i własnej grupy. Co ciekawe, narratorka unieważnia prawomocność rosyjskiej hegemonii kulturowej nie za pomocą obrony wysokiej wartości kultury własnej (białoruskiej), jak wymagałyby zasady stylistycznej symetrii. Uznaje wielkość języka i kultury rosyjskiej: „rozumiem Dostojewski $\backslash$ Tołstoj $\backslash$ Puszkin \” [7:46], z tym jednak zastrzeżeniem, że należy wprowadzić rozróżnienie na kulturę rosyjską i cywilizację rozumianą jako wysoki poziom życia obywateli: „zresztą uważam że wielkiej kulturze powinna towarzyszyć wielka cywilizacja \ponieważ (.) słonecznie mroźnie cudny ranek $^{22}$ / po prostu (5) nie brzmi\ w kurnej chacie z klepiskiem\" [7:47-49]. Narratorka kwestionuje emancypacyjną rolę przypisywaną przez rozmówczynię-Rosjankę radzieckim wyzwolicielom: „kiedy tu [na Białoruś] przyszliśmy/ (...) ona mówi czyli ich bolszewicy w łapciach dopiero żeście wszyscy chodzili`" [04:12-13]. Alesia twierdzi, że - wręcz przeciwnie - to Białorusini byli cywilizacyjnie bardziej zaawansowani: „kiedy Ruscy tu wkroczyli/ (.) rabowali miejscowych a ich żony/ (.) chodziły do lokalnego teatru (.) ubrane w koszule nocne \uważając że są to suknie letnie" [04:14-16].

Przykład Alesi pokazuje, że na Białorusi proces przedefiniowania zbiorowej i jednostkowej tożsamości narodowej może być niezwykle bolesny, w dużej mierze może oscylować wokół zdefiniowania zbiorowości „my” i „oni” z wykorzystaniem dychotomii „ofiara”-,oprawca”, co pomaga w nazywaniu obcych i tworzeniu wobec nich dystansu. Historia ułożyła się tak, że w toku dziejów Polska i Białoruś wielokrotnie były uwikłane w relacje centrum-peryferie. O ile Rosja (a w okresie 1917-1990 Związek Radziecki) niejednokrotnie była wspólnym oprawcą i centrum decyzyjnym w stosunku do Białorusi i Polski, o tyle Polska aż do połowy wieku XIX pełniła rolę centrum i hegemona kulturowego wobec Białorusi 23 .

\section{UWAGI KOŃCOWE}

Ostatnia dekada ubiegłego stulecia to w Europie Środkowo-Wschodniej okres radykalnych przemian, którym towarzyszył renesans badań biograficznych. Pomagają one uchwycić proces i mechanizmy radzenia sobie ze zmianą, problemy zachowywania ciągłości biografii, spójnego obrazu siebie, a także tożsamości (por. Miller i in. 2005). Okres gwałtownych przemian społecznych i ustrojowych, „kiedy rutynowe dopasowanie struktur subiektywnych do obiek-

22 Cytat z wiersza Aleksandra Puszkina Zimowy poranek, w tłumaczeniu Heleny Bychowskiej.

23 Należy pamiętać, że w dużym uproszczeniu tereny dzisiejszej Białorusi odpowiadają mniej więcej obszarowi Wielkiego Księstwa Litewskiego, a tereny dzisiejszej Litwy odpowiadają w przybliżeniu dawnej Żmudzi. Rzeczpospolita zatem przez długi czas stanowiła polsko-białorusko-ukraińsko-litewski commonwealth, politycznie i kulturowo zdominowany przez Polskę. 
tywnych jest nagle przerwane" (Bourdieu, Wacquant 2001, s. 120), pozwala dostrzec ujawniony habitus wraz z systemem dyspozycji i kategoryzacji, które nie przystają do zmienionych okoliczności (por. Miller i in. 2005).

Co ciekawe, w przypadku wszystkich omówionych narracji daje się wyodrębnić „punkt zwrotny” w biografii, kiedy to zwykły dotychczas obywatel radziecki odkrywa swoją białoruską tożsamość. Nie bez znaczenia pozostaje fakt, że moment „przebudzenia” następuje w okresie pierestrojki poprzedzającym rozpad Związku Radzieckiego: „no i w czasach pierestrojki $\backslash$ zaczęły się sączyć te rozmowy (.) w sklepach na przykład no kiedy już Litwini się oddzielili Łotysze i nawet Białoruś zaczęła przebąkiwać o niepodległości〉" [wywiad z Alesią, 3:22-24]. Owo odkrycie własnej, niezafałszowanej, jednak do tego momentu uśpionej świadomości następuje w odpowiednim czasie historycznym: „rok osiemdziesiąty trzeci już no przemiany się jeszcze nie odbywały w Związku Radzieckim ale coś już w powietrzu wisiało\" [wywiad z Wiktorem, 4:12-14].

Narracje Wiktora i Lawona odsłaniają także rolę znaczących innych i grupy odniesienia w kształtowaniu się białoruskiej tożsamości narodowej, co polegało między innymi na wzbogacaniu wiedzy z zakresu narodowej symboliki i historii, „alternatywnej” względem historiografii radzieckiej. Wszystkie omówione wywiady, ze szczególnym uwzględnieniem narracji Alesi i Wiktora, ukazują powiązania między pamięcią historyczną a biograficzną (por. Halbwachs 2008), która $z$ kolei jest nierozerwalnie związana $z$ tożsamością grupy. Odsłonięto skomplikowany proces kształtowania się tożsamości indywidualnej i zbiorowej we współczesnej Białorusi, państwie autorytarnym, o spornej pamięci zbiorowej, w którym nie istnieje pole swobodnej wymiany czy pracy nad pamięcią. Szkicując występujący w dzisiejszej Białorusi kontekst pamięci historycznej, z której - podobnie jak z pamięci biograficznej, zdaniem Halbwachsa (2008) - czerpie pamięć zbiorowa, należy zwrócić uwagę na współistnienie urzędowej, zsowietyzowanej historiografii tworzonej przez „nadwornych historyków urzędującego prezydenta i ocenzurowanej historiografii historyków dysydenckich, reprezentujących tak zwaną szkołę Dounara-Zapolskiego (Radzik 2001). Ta pierwsza stanowi oficjalną wersję historii obowiązującą na wszystkich etapach systemu edukacji, przedstawianą na łamach podręczników do historii i w mediach państwowych. Ta druga to ocenzurowana wersja historii, rozpowszechniana nieoficjalnymi kanałami w środowisku „wtajemniczonych”. Pod rządami autorytarnego prezydenta na Białorusi brakuje forum nieocenzurowanej wymiany pamięci biograficznej lub pracy nad pamięcią zbiorową, ponieważ dyskurs publiczny nie został poddany demokratyzacji. Ocenzurowana białoruska pamięć narodowa przemieszcza się kanałami wymiany niepublicznej oraz funkcjonuje w przekazach międzypokoleniowych i historiach życia rodzin (por. Pomian 2006). Ciągłość pamięci jest dodatkowo utrudniona z powodu braku białoruskich miejsc pamięci (Nora 1989, 1998) i ocenzurowania części dziedzictwa kulturowego. 
Objęte analizą interpretacyjną wywiady przeprowadzono $z$ narratorami w podobnym wieku, którzy zaczęli odkrywać swoją białoruską tożsamość jako osoby dorosłe. Rodzice Wiktora i ojciec Alesi (matka narratorki zmarła tuż po jej urodzeniu) mówili po rosyjsku, rodzice Lawona — przeważnie po białorusku (również z racji wykonywanego zawodu). Wszyscy troje odebrali wykształcenie $w$ języku rosyjskim, $z$ wyjątkiem takich przedmiotów, jak język i literatura białoruska. Pochodzą z rodzin o mieszanych korzeniach etnicznych, więc mogli deklarować tożsamość inną niż białoruska. Dokonując jednak świadomego wyboru tożsamości białoruskiej, opowiedzieli się po stronie „swojskości” i odrzucili tożsamość rosyjską. Odkrywaniu przynależności do białoruskiego uniwersum symbolicznego towarzyszy refleksja nad wyborem języka białoruskiego jako narzędzia komunikacji w kraju, w którym język ten jest używany przez mniejszość mieszkańców Mińska lub Grodna, w miejscu zamieszkania narratorów. W wyniku pracy biograficznej Alesia uznaje doniosłą rolę języka białoruskiego, na co dzień używa jednak języka rosyjskiego, po białorusku mówi jedynie $\mathrm{w}$ wybranych sytuacjach, na przykład $\mathrm{w}$ transporcie publicznym. Wiktor całkowicie przestawia się na język białoruski w pracy i życiu codziennym, wychodząc $z$ założenia, że na poziomie pasywnym wszyscy mieszkańcy Białorusi rozumieją swój język ojczysty. Lawon posługuje się białoruskim w pracy, a w życiu codziennym mówi po białorusku lub rosyjsku w zależności od języka, którym posługuje się interlokutor.

Język jest narzędziem komunikacji. Wybierając język, jednostka wybiera swoją wspólnotę komunikacyjną. Na Białorusi w obrębie jednego państwa istnieje więcej niż jedna zbiorowość o charakterze kulturowym. Przypomina to sytuację Polski z okresu PRL, a jeszcze bardziej z okresu zaborów, kiedy to wspólistniały oficjalny i „drugi” obieg kultury. Adresaci wytworów oficjalnego i drugiego obiegu kultury należeli do różnych uniwersów symbolicznych, mimo że zamieszkiwali teren tego samego państwa. Sytuacja ta jest typowa dla państw autorytarnych, do których zaliczamy współczesną Białoruś, gdzie wybór języka białoruskiego lub rosyjskiego jest wyborem o zabarwieniu ideologicznym, który rzutuje między innymi na ścieżkę kariery zawodowej i wybór uniwersum symbolicznego.

$\mathrm{Na}$ Białorusi język białoruski ma nie tylko wartość symboliczną, jest to mocna broń polityczna. Łukaszenka kontynuuje radziecką politykę dwujęzyczności, w myśl której białoruskość była postrzegana jako wtórna wobec radzieckości. Najpierw należało się czuć obywatelem Związku Radzieckiego, a dopiero w drugiej kolejności - obywatelem Białorusi. Szowinistyczna polityka władz radzieckich miała na celu stworzenie obywatela nowego gatunku, który podporządkuje się władzy kosztem zachowania własnej tożsamości, a bycie członkiem narodu radzieckiego ceni bardziej niż przynależność do wspólnoty narodowej lub etnicznej (Lazari 1995, s. 101-102). W Związku Radzieckim funkcjonowało pojęcie „drugiego języka ojczystego”, przy czym zakładano, że „pierwszym językiem ojczystym" dla wszystkich obywateli radzieckich był język rosyjski. 
Promowany był także wizerunek języka rosyjskiego jako języka kultury wysokiej (początkowo w swoich przemówieniach Łukaszenka podkreślał wyższość kultury i języka rosyjskiego; zob. Goujon 1999), a języków narodowych jako języków życia codziennego. Warto tu odnotować, że takie podejście do języków narodowych cechowało większość państw imperialnych, na przykład Wielką Brytanię (zob. Eames 1997).

Łukaszenka wykorzystał tę retorykę pozornej równości języków i narodowości, w referendum z 1995 r. zadając pytanie „Czy zgadzasz się, aby język rosyjski miał równy status $z$ językiem białoruskim?”, na które $83,1 \%$ zapytanych odpowiedziało twierdząco. Potem wystarczyło wprowadzić zmiany do „Ustawy o języku” (przyjętej w styczniu 1990 r.) w rodzaju „rozporządzenia mogą być wydawane w języku białoruskim i (lub) rosyjskim", i powrócić tym samym do stanu sprzed upadku Związku Radzieckiego. Mimo populistycznych zapewnień o równości obu języków przywrócono zatem stan nierównowagi znany $z$ czasów radzieckich, kiedy to elity polityczne nie miały obowiązku stosowania języka białoruskiego w mowie i piśmie. Język rosyjski ponownie stał się językiem władz państwowych, a język białoruski - językiem opozycji.

\section{BIBLIOGRAFIA}

Andrusieczko P., 2003, Ukraina - Biatoruś, różnice - podobieństwa, w: Kamil Kłysiński, Radosław Witek (red.), Białoruś - czas zmian, Rys, Poznań.

Atkinson Maxwell, Heritage John, 1984, The Structure of Social Action, Cambridge University Press, Cambridge.

Berlin Isaiah, 2003, Rosyjscy myśliciele, tłum. Sergiusz Kowalski, Prószyński i S-ka, Warszawa.

Bhabha Homi, 2010, Miejsca kultury, tłum. Tomasz Dobrogoszcz, Wydawnictwo Uniwersytetu Jagiellońskiego, Kraków.

Bourdieu Pierre, Wacquant Loïc J. D., 2001, Zaproszenie do socjologii refleksyjnej, tłum. Anna Sawisz, Oficyna Naukowa, Warszawa.

Brzeziecki Andrzej, Nocuń Małgorzata, 2007, Ograbiony naród. Rozmowy z intelektualistami białoruskimi, Kolegium Europy Wschodniej im. Nowaka-Jeziorańskiego, Wrocław.

Bułhakau Walery, 2002, Wybory prezydenckie w roku 2001 a tożsamość kulturowa Biatorusinów, „Lithuania”, nr 1-2.

Chanfrault-Duchet Marie, 1995, Biographical Research in Former West Germany, „Current Sociology", t. 43, nr 2-3, s. 209-219.

Czyżewski Marek, 1997, Wprowadzenie do tekstu Fritza Schützego, „Studia Socjologiczne”, nr 1.

Donskis Leonidas, 1999, The Conspiracy Theory, Demonization of the Other, „Innovation”, t. 11, nr 3, s. 349-360.

Eames Marion, 1997, A Private Language? A Dip into Welsh Literature, Gomer Press Llandysul, Ceredigion.

Furman Dmitrii, 1999, Centers and Peripheries: The Political Systems of the Three East Slavic Republics, „Russian Social Science Review”, t. 40, nr 6. 
Gandhi Leela, 2003, After Colonialism, w Roland Robertson, Kathleen E. White (red.), Globalization: Critical Concepts in Sociology, t. 2, Routledge, London-New York.

Garoszka Leu, 1994, Pryczyny palanizacji na Biełarusi, „Świtiaź”, nr 1, s. 99-116.

Goujon Alexandra, 1999, Language, Nationalism, and Populism in Belarus, „Nationalities Papers", t. 27, nr 4, s. 661-677.

Halbwachs Maurice, 2008, Spoteczne ramy pamięci, tłum. Marcin Król, Wydawnictwo Naukowe PWN, Warszawa.

Helling Ingeborg, 1990, Metoda badań biograficznych, w: Jan Włodarek, Marek Ziółkowski (red.), Metoda biograficzna $w$ socjologii, PWN, Warszawa-Poznań.

Hermanns Harry, 1987, Narrative Interviews - a New Tool for Sociological Field Research, „Folia Sociologica”, nr 13, s. 43-56.

Hutchby Ian, Wooffitt Robin, 1998, Conversation Analysis, Polity Pres, Cambridge.

Ihnatouski Usiewaład, 1992, Karotki narys historyi Bełarusi, Belarus, Mińsk.

Jalusic Vlasta, 2007, Organized Innocence and Exclusion: „Nation-States” in The Aftermath of War and Collective Crime, „Social Research”, t. 74, nr 4, s. 1173-1200.

Janowicz Sokrat, 2001, Ojczystość. Białoruskie ślady i znaki, tłum różni, Borussia, Olsztyn.

Kaźmierska Kaja, 1997, Wywiad narracyjny — technika i pojęcia analityczne, w: Marek Czyżewski, Andrzej Piotrowski, Alicja Rokuszewska-Pawełek (red.), Biografia a tożsamość narodowa, Uniwersytet Łódzki, Łódź.

Kłoskowska Antonina, 1996, Kultura narodowa u korzeni, Wydawnictwo Naukowe PWN, Warszawa.

Korzeniewski Bartosz, 2006, Polityczne rytuaty pokuty w perspektywie zagadnienia autonomii jednostki, Wydawnictwo Poznańskie, Poznań.

Krakowiak Tomasz, Mamul Natalia, 2008, „Bycie ofiara” jako strategia $w$ dyskursach o przeszłości, Wydawnictwo Uniwersytetu Łódzkiego, Łódź.

Krawcewicz Aleksander, 2003, Powstanie Wielkiego Księstwa Litewskiego, Wydawnictwo Wyższej Szkoły Ekonomicznej w Białymstoku, Białystok.

Lazari Andrzej (red.), 1995, The Russian Mentality Lexicon. Ideas in Russia, Śląsk, Katowice.

Lenzi Mark, 2002, Lost Civilization: The Thorough Repression of Civil Society in Belarus, „Demokratizatsiya”, t. 10, nr 3, s. 401-424.

Miller Robert, Humphrey Robin, Zdravomysłova Elena, 2005, Biographical Research and Historical Watersheds, w: Robert Miller (red.), Biographical Research Methods, Sage Publications, London.

Mironowicz Eugeniusz, 2002, The Attitudes of Belarusians and Poles Toward the Independence of Their Countries, „International Journal of Sociology”, t. 31, nr 4, s. 79-89.

Mironowicz Eugeniusz, 2007, Białoruś, Trio, Warszawa.

Nora Pierre, 1989, Between Memory and History: Les Lieux de Mémoire, „Representations”, nr 26, Special Issue: Memory and Counter-Memory, Spring, s. 7-24.

Nora Pierre, 1998, The Era of Commemoration (the afterword), w: Pierre Nora, Lawrence D. Kritzman (red.), Realms of Memory: Rethinking the French Past, Columbia University Press, New York, t. 3: Symbols, tłum. Arthur Goldhammer.

Pankowiec Zmicier, 2007, Tu rodzit się naród. Kuropaty - masowa mogiła setek tysięcy ludzi, tłum. Małgorzata Nocuń, „Tygodnik Powszechny”, 29 lipca.

Piotrowski Andrzej, 1997, Wstęp, w: Marek Czyżewski, Andrzej Piotrowski, Alicja Rokuszewska-Pawełek (red.), Biografia a tożsamość narodowa, Uniwersytet Łódzki, Łódź.

Pomian Krzysztof, 2006, Historia urzędowa, historia rewizjonistyczna, historia krytyczna, „Przegląd Polityczny”, nr 77. 
Prawda Marek, 1989, Biograficzne odtwarzanie rzeczywistości, „Studia Socjologiczne”, nr 4. Radzik Ryszard 2001, Belarus between the East and the West: The Soviet-Russian Option versus the Nationalist Option in Belarusian Society, „International Journal of Sociology”, t. 31, nr 3, s. 11-45.

Radzik Ryszard, 2002, Kim sa Biatorusini?, Wydawnictwo Adam Marszałek, Toruń.

Riemann Gerhard, 2000, „Introduction. The idea of this project”, Otto-Friedrich-Universität Bamberg, maszynopis.

Riemann Gerhard, Schütze Fritz, 1992, „Trajektoria” jako podstawowa koncepcja teoretyczna w analizach cierpienia i bezładnych procesów społecznych, „Kultura i Społeczeństwo”, $\mathrm{nr} 2$.

Rokuszewska-Pawełek Alicja, 1996, Miejsce biografii w socjologii interpretatywnej. Program socjologii biografistycznej Fritza Schützego, „ASK”, nr 1.

Sacks Harvey, Schegloff Emanuel A., Jefferson Gail, 1974, A Simplest Systematics for the Organization of Turn-Taking for Conversation, „Language”, t. 50, nr 4, s. 696-735.

Schütze Fritz, 1990, Presja $i$ wina: doświadczenia młodego żotnierza niemieckiego $w$ czasie II wojny światowej $i$ ich implikacje biograficzne, w: Jan Włodarek, Marek Ziółkowski (red.), Metoda biograficzna $w$ socjologii, PWN, Warszawa-Poznań.

Schütze Fritz, 1997, Trajektorie cierpienia jako przedmiot badań socjologii interpretatywnej, „Studia Socjologiczne”, nr 1.

Sidorov Dmitrii, 2006, Post-imperial Third Romes: Resurrections of a Russian Orthodox Geopolitical Metaphor, „Geopolitics”, t. 11, s. 317-347.

Smułkowa Elżbieta, 2002, Białoruś i pogranicza. Studia o jezzku i społeczeństwie, UW, Warszawa.

Stone Daniel, 2001, The Polish-Lithuanian State, 1386-1795, University of Washington Press, Seattle-London.

Straczuk Justyna, 1999, Język a tożsamość cztowieka, Wydawnictwo Uniwersytetu Warszawskiego, Warszawa.

Strauss Anselm L., 1975, Chronic Illness and the Quality of Life, The C.V. Mosby Company, San Francisco.

Szybieka Zachar, 2002, Historia Biatorusi 1795-2000, Instytut Europy Środkowo-Wschodniej, Lublin.

Tereshkovich Pavel, 2001, The Belarusian Road to Modernity, „International Journal of Sociology", t. 31, nr 3, s. 78-93.

Wertsch James V., 2008, Collective Memory and Narrative Templates, „Social Research”, t. 75, nr 1, s. 133-155.

Zaprudnik Jan, 1996, Biełaruś. Na histarycznych skryżawanniach, Biełaruski Fond Sorasa, Baćkauszczyna, Minsk.

\section{LANGUAGE AS A FACTOR OF ROOTING WITHIN NATIONAL IDENTITY}

\section{A CASE OF BELARUSSIAN-SPEAKING INTELIGENTSIA IN BELARUS}

\section{Summary}

Belarus is a typical borderline country featuring multi-ethnicity, including various cultures, denominations and languages co-existing one near the other. Current socio-linguistic situation in Belarus may be defined as socially conditioned diglossia. Russian is the language of the governing elites, all-level education, popular culture and mass 
media. Urban inhabitants speak almost entirely Russian, and the majority of village inhabitants speak Belarusian dialects. When, during Lukaszenka's rule, Belarusian language fell once again in disgrace, it once again became a symbol of national revival and a fighting tool of opposition. Representatives of democratic elites speak Belarusian, but only when they hold informal meetings or political events.

Based on biographic interviews held with the representatives of the Belarusian intelligentsia in Belarus, the Author has revealed a process of the narrators' discovering an importance of a mother tongue as a sign of national identity. The process of realizing the importance of the Belarusian language in the life of an individual, as well as ethnic community, as well as a process of conscious learning of the language is, for contemporary Belarusians, one of the stages of shaping national identity. Learning the language is followed by participating in Belarusian symbolic culture and remembering history and reviving common memory, which finally leads to conscious identity with a mother land in a symbolic sense, which is broader than purely territorial reference.

\section{Key words/słowa kluczowe}

national identity / tożsamość narodowa; Belarus / Białoruś; narrative interview / wywiad narracyjny 